International Journal of Economics, Business and Management Research

Vol. 6, No.02; 2022

ISSN: $2456-7760$

\title{
Factors Affecting the Acceptance of the Raileo Application and Their Impact on Worker Performance of PT Kereta Api Indonesia (Persero) Daop V Purwokerto
}

\author{
Yusuf Abdullah $^{1}$, Salamah Wahyuni ${ }^{2}$ \\ ${ }^{1}$ Faculty of Economics and Business, Sebelas Maret University, \\ Surakarta, Indonesia \\ ${ }^{2}$ Faculty of Economics and Business, Sebelas Maret University, \\ Surakarta, Indonesia
}

doi: 10.51505/ijebmr.2022.6214 URL: http://dx.doi.org/10.51505/ijebmr.2022.6214

\begin{abstract}
This Online Presence in addition to making it easier to record attend ance, can also be used to ease the work of employees in making monthly attendance reports. Ease and efficiency in the use of the presence system is an added value in supporting the effectiveness of work in an agency. The implementation of KAI Mobile Presence which came into effect in October 2019 and was developed in October 2020 to become RAILEO is still not optimal, so there is a need for research that the implementation of RAILEO can be accepted and implemented as well as possible by all employees of PT. KAI (Persero) Daop V Purwokerto. From this background, this study aims to analyze the factors that influence the acceptance of the RAILEO application and its impact on the performance of PT. Kereta Api Indonesia (Persero) DAOP V Purwokerto. The benefits of this research are expected to improve the performance of workers at PT. Kereta Api Indonesia (Persero) Daop V Purwokerto. The research was conducted at PT. Kereta Api Indonesia (Persero) DAOP V Purwokerto and The results in this study are: (1) perceived usefulness affects the acceptance of the RAILEO application, (2) the ease of use affects the acceptance of the RAILEO application, (3) security and privacy affect the acceptance of the RAILEO application, (4) the quality of the internet network affects the acceptance RAILEO application, (5) acceptance of RAILEO application affects performance and (6) perceived enjoyment has no effect on acceptance of RAILEO application.
\end{abstract}

Keywords: Online Presence, RAILEO application, PT. KAI DAOP V, Performance

\section{Introduction}

Information technology is a technology used to process data, including processing, obtaining, compiling, storing, manipulating data in various ways to produce quality information, namely information that is relevant, accurate and timely, can also be used for personal, business, and governance which is strategic information for decision making (Saiful Rahman Yuniarto, 2016). Research conducted by Agil et al., (2014) entitled The Influence of the Use of Information Technology on Performance, the results of the research state that Wireless Information Technology and Wireline Information Technology have a simultaneous and significant effect on employee performance at PT. PLN Area Madiun. By utilizing the development of information 


\section{International Journal of Economics, Business and Management Research}

Vol. 6, No.02; 2022

ISSN: $2456-7760$

technology in the company, in September 2019 the company's internal regulation PT. KAI (Persero) which regulates the use of presence to support electronic-based worker discipline, namely E-Gate, Fingerprint and application-based using KAI Mobile Presence which must be implemented starting in October 2019, the company developed the KAI Mobile Presence application into RAILEO which was initially only a service for Worker's online presence becomes several other services, namely online attendance, official travel submissions, application for leave and permission to not come to work / late, making a locomotive ride permit card (O.23), printing curriculum vitae and salary slips, submission of health conditions (self assessment), and download/read Contact's internal tabloid.

This Online Presence in addition to making it easier to record attendance, can also be used to ease the work of employees in making monthly attendance reports. Ease and efficiency in using the presence system is an added value in supporting work effectiveness in an agency (Forbes, 2017). PT. Kereta Api Indonesia (Persero) Daop V Purwokerto has a working area from the north side, namely from Slawi Station to Kroya Station and from the south side, from Langen Station to Kutoarjo Station. Located in 7 districts, namely Tegal, Brebes, Ciamis, Banyumas, Cilacap, Kebumen and Purworejo (https://ppid.kai.id). The office of Daop V Purwokerto is located in Purwokerto, Banyumas Regency. Total active workers of PT. KAI Daop V Purwokerto as many as 1,885 spread across the working area of PT. KAI Daop V Purwokerto. (https://eoffice.kai.id). In relation to the performance of workers, the data obtained from the Human Resources unit of PT. KAI Daop V Purwokerto, as many as 214 people whose performance samples were taken, it can be seen that of the current 214 workers whose performance is adequate, 73 workers or $34 \%, 124$ workers or $58 \%$ good performance and 17 workers or $8 \%$ which performs very well. From these data, there are still workers who have sufficient and not optimal performance.

The concept of Acceptance Model Theory (TAM) developed by Davis (1989), conveys a theory as a basis for studying and understanding user behavior in receiving and using an information system. TAM provides a strong and simple explanation in accepting technology and the behavior of its users (Davis, 1989). TAM has the aim of explaining and predicting user acceptance of the factors that influence the acceptance of a technology in an organization. TAM describes a causal relationship between beliefs and behavior, goals/needs, and the actual use of users/users of an information system. The TAM model explains in more detail about internet acceptance with certain dimensions that can affect internet users easily. This model places the trust factor of each user behavior with two variables, namely usefulness and ease of use. This model has been shown to provide an empirical description of the behavioral aspects of computer users, where many users can easily operate the internet, because it is in accordance with what they want to improve performance (Iqbaria et al., 1994).

According to Hon (2013), performance is basically what employees do and don't do. Employee performance affects how much they contribute to the organization. Hon (2013) further provides a standard for a person's performance which can be seen from the quantity of output, quality of output, duration of output, attendance at work and cooperative attitude. The performance standards are set based on job criteria, namely explaining what the organization has given its 


\section{International Journal of Economics, Business and Management Research}

Vol. 6, No.02; 2022

ISSN: $2456-7760$

employees to do, therefore individual performance in job criteria must be measured, compared to existing standards and the results must be communicated to all employees. Hon (2013) also explains that performance standards can be in the form of production output or better known as numerical performance standards and non-numeric performance standards.

The quality of employee work directly affects the company's performance. In order to get optimal employee contributions, management must understand in depth the strategies to manage, measure and improve performance, which starts with determining performance benchmarks (Sinambela, 2012).

Research conducted by Pikkarainen et al., (2004) explains the results that online banking in the banking sector has a positive effect on current technological advances. The limitation of the research conducted by Pikkarainen is that further research is still needed by adding other variables and in other sectors to find out the technology of the RAILEO Application. From this, this research continues from research conducted by Pikkarainen by adding intervening variables and is carried out in the service sector, namely at PT. KAI Daop V Purwokerto.

From the above background, the purpose of this study is to test the perceived usefulness of workers on the acceptance of the RAILEO application, to test the perceived ease of use of workers to the acceptance of the RAILEO application, to test the enjoyment felt by workers to the acceptance of the RAILEO application, to test the safety and privacy of workers. affect the acceptance of the RAILEO application, testing the quality of the internet network affects the acceptance of the RAILEO application and testing the acceptance of the RAILEO application has an effect on performance.

The purpose of this study was to test the perceived usefulness of workers on the acceptance of the RAILEO application, to test the perceived ease of use of workers to the acceptance of the RAILEO application, to test the enjoyment felt by workers to the acceptance of the RAILEO application, to test the safety and privacy of workers to the acceptance of the RAILEO application. testing the quality of the internet network affects the acceptance of the RAILEO application and testing the acceptance of the RAILEO application has an effect on performance. The limitation of this research is that this research only examines the factors that influence the acceptance of RAILEO applications and their impact on performance and the object of research at PT. Kereta Api (Persero) Daop V Purwokerto.

\section{Theory \& Hypothesis Development}

Organizational Support Theory

According to Eisenberg, et al., (1990) stated that organizational support is an employee's belief about how much the company supports the employee's work and the welfare of the employee concerned. The company's treatments received by employees are considered as stimuli that are organized and interpreted into perceptions of organizational support.

Fuller, et. al., (2016) stated: Organizational support as an employee's assessment of the organization's support or concern for him. Eisenberger, et. al., (2016) stated that organizational support refers to employees' perceptions of the extent to which the organization values their 


\section{International Journal of Economics, Business and Management Research}

Vol. 6, No.02; 2022

ISSN: $2456-7760$

contributions and cares about their welfare. If employees perceive that the organizational support they receive is high, then the employee will integrate membership as a member of the organization into their identity and then develop a more positive influence and perception of the organization.

According to Kambu (2012) the concept of organizational support describes the interaction of individuals with organizations that specifically study how the organization treats its employees. Perceived organizational support is defined as employees' perceptions of the extent to which the organization values employee contributions and cares about their well-being (Ucar \& Otken, 2010 in Dewi and A.A. Sagung (2018)).

According to Danish, Ramzan and Ahmad (2013:313), organizational support is an employee's expectation that the organization appreciates contributions and the work that employees do well. According to Robbins (2015: 278) organizational support is where the organization faces a dynamic and changing environment so that the organization adapts.

\section{Technology Acceptance Model}

According to Davis (1989) the Technology Acceptance Model (TAM) predicts acceptance of the use of technology based on the influence of two cognitive factors, namely perceived usefulness and perceived ease of use. TAM is based on Theory of Reasoned Action (TRA) proposed by Ajzen and Fisbein (1980). TRA explains the reactions and perceptions of users of information technology which ultimately affects their attitude in accepting the technology.

The purpose of TAM is to explain the external factors of the behavior of users of information technology on the acceptance of the use of information technology itself. TAM explains the acceptance of information technology with certain dimensions that can affect the acceptance or not of information technology by users (users). Empirically TAM has been shown to provide an overview of the behavioral aspects of PC users, where many PC users can easily accept an information technology because it is in accordance with what they want (Igbaria et al., 1997 in Nasution, 2004 in Jurica Lucyanda, 2010).

\section{RAILEO Application Admission}

The application of technology in a company to facilitate personnel services, health, operations and company internal information is very necessary. The development of this technology is needed by employees to facilitate the completion of tasks. According to Arifin and Pratolo (2012) that there are three aspects that must be achieved to achieve the target of achieving the target of the application of information technology, namely that information technology must directly or indirectly have an impact on the creation of service products that are much better than before so as to improve performance. and company competitiveness.

One of the services of the RAILEO Application is online attendance for PT. KAI (Persero). According to Wardhana, (2014). Attendance System is a personal attendance management system or an institution or agency that automatically records attendance data and can be used as a source of reports for personal management needs. Meanwhile, according to (Ali and Nasr, 2016) 


\section{International Journal of Economics, Business and Management Research}

Vol. 6, No.02; 2022

ISSN: $2456-7760$

Attendance is the recording and processing of attendance data that is carried out continuously, recording is carried out every working hour and reporting to the HRD / Company Manager.

According to (Mulis, 2009), the presence application program is an application that is engaged in the employee data collection process, which consists of inputting employee data, employee attendance data and printing reports. Employee data collection aims to enter employee data. Employee attendance data aims to enter employee attendance data consisting of hours of entry, hours of exit and printing of employee reports aims to print the results of employee data consisting of hours of entry and hours of exit.

\section{Performance}

Increasing productivity is a central issue in today's organizations. Productivity through job performance stands as a widely researched domain in the organizational behavior (OB) and human resource development (HR) literature. Employee performance is the work achieved by a person or group of people in accordance with the authority or responsibility of each employee during a certain period (Pradhan and Jena, 2017). A company needs to conduct a performance appraisal on its employees. Performance appraisal plays a very important role in increasing motivation in the workplace. Assessment should provide an accurate picture of work performance.

Performance is the result of work in quality and quantity achieved by an employee in carrying out his duties in accordance with the responsibilities given to him (Mangkunegara, 2007: 67). Performance has a broader meaning, not only as a result of work but including how the work process takes place (Wibowo, 2010).

Sedarmayanti (2007) states that performance is a system used to assess and find out whether an employee has carried out his work as a whole, or is a combination of work results (what a person must achieve) and competence (how a leader is in carrying out his leadership system).

Furthermore, Mangkunegara (2006) stated that the performance of Human Resources is a term from the word Job Performance or Actual Performance (Work Achievement) is the result of work in quality and quantity achieved by an employee/employee in carrying out his duties in accordance with the responsibilities given to him.

Performance is an embodiment made by employees which is usually used as a basis for evaluating employees or organizations. Good performance is a step towards achieving organizational goals. Therefore, performance is a determinant in achieving organizational goals. So it is necessary to strive to improve performance, even though it is not easy because many factors cause a person's performance to be high or low. Many theories have been put forward regarding the factors that affect performance, both personally, which have physical and psychological characteristics (Tito Irwanto, et al.,).

Discipline is an attitude that is needed and gets the attention of every village apparatus in an effort to improve performance. Discipline is the most important operative function of human resource management because the better the employee discipline, the higher the work 


\section{International Journal of Economics, Business and Management Research}

Vol. 6, No.02; 2022

ISSN: $2456-7760$

performance that can be achieved. Without good discipline, it is difficult for corporate organizations to achieve optimal results (Fathoni, 2006:126). According to Sinambela (2012: 239), "work discipline is a person's ability to work regularly, diligently continuously and work in accordance with applicable rules without violating the rules that have been set". Wirawan added (2009: 138), "discipline is the attitude and behavior of compliance with organizational regulations, work procedures, codes of ethics, and other organizational cultural norms that must be obeyed in producing a product and serving the organization's consumers". Judging from the opinions of these experts, it can be concluded that discipline is an effort to instill value in creating an attitude of obedience to certain work rules and being responsible for their work.

\section{Hypotheses}

Terro Pikkarainen, et al., (2004) stated that the perceived usefulness and the amount of information in online banking are the most influential factors in explaining the use of online banking services. This finding refers to the fact that consumers use online banking for profit. In another study conducted by Davis, et al (1989), stated that perceived usefulness is defined as "the extent to which a person believes that using a particular system will improve his job performance. Based on these references can be formulated

H1: The perceived usefulness of workers has a positive effect on the acceptance of the RAILEO application.

Terro Pikkarainen, et al., (2004) in their research explains the fact that when customers learn about the ease of using online banking applications, the impact becomes important and shows that consumers get more information about online banking, they become more informative about the benefits it offers. In a previous study conducted by Davis, Fred (1989) stated that perceived ease of use, on the other hand, refers to "the degree to which a person believes that using a particular system will be effort-free. All other things being equal, applications are perceived to be easier to use than intended. others are more likely to be accepted by users. In another study conducted by Heriyati and Prasetyo (2018) suggested that the ease of use felt by workers affected the acceptance of Online Presence. Based on these references, it can be formulated

$\mathrm{H} 2$ : The ease of use felt by workers affects the acceptance of the RAILEO Application

Terro Pikkarainen, et al., (2004) stated that they found that perceived pleasure had a significant impact on intention to use the Internet. Enjoyment refers to the degree to which the activity of using a computer is considered enjoyable by itself (Davis et al., 1992). Perceived enjoyment is positively correlated with time of use but not with frequency of use or number of tasks (Igbaria et al., 1995). On the other hand, Teo et al., (1999) noted that perceived enjoyment is positively correlated with the frequency of daily internet use. Based on these references, it can be formulated

H3: The enjoyment felt by workers affects the acceptance of the RAILEO Application

Terro Pikkarainen, et al., (2004) stated that security and privacy did not significantly influence the acceptance of online banking. This is related to previous research which explained in the application of online systems that privacy and security were found to be significant barriers to online banking adoption in Australia (Sathye, 1999). Roboff and Charles (1998) found that 


\section{International Journal of Economics, Business and Management Research}

Vol. 6, No.02; 2022

ISSN: $2456-7760$

people have a weak understanding of the security risks of online banking even though they are aware of these risks. In addition, they found that consumers often rely on banks to pay more attention to privacy issues and protect them. Finally they argue that while consumers' trust in their bank is strong, their trust in technology is weak (see also Howcroft et al., 2002). According to many studies (eg Westin and Maurici, 1998; Cranor et al., 1999) privacy issues have proved an important barrier to the use of online services. Based on these references, it can be formulated

H4: Workers' security and privacy affect the acceptance of the RAILEO Application

The results of a study conducted by Tero Pikkarainen, et al., (2004) stated that the internet quality factor implies that the speed and reliability of the internet connection is not considered important due to the fact that a reliable internet connection has become common among the respondents. But in another study conducted by Windi et al., (2020) said that the factor that hinders the effectiveness of the application of fingerprint attendance at BPPKAD Brebes Regency is that the attendance facility or machine often experiences errors, thus hampering the process of recording employee attendance because the system is based online when the network is on. is experiencing a disturbance, then the activities in BPPKAD will be disrupted. Based on these references can be formulated

H5: The quality of the internet network affects the acceptance of the RAILEO application.

Based on the research results of Muhammad Hilmi Muzakkki, et al., (2016) that Information Technology has a significant influence on employee performance simultaneously and partially. Another study conducted by Astuti Handaiyani Siregar, et al., (2009) that the use of technology has a positive and significant effect on individual performance at the West Denpasar Pratama Tax Service Office. Based on the results of this study, online presence which is the result of technological developments is expected to improve employee performance. Based on these references can be formulated

H6: Acceptance of the RAILEO Application affects performance.

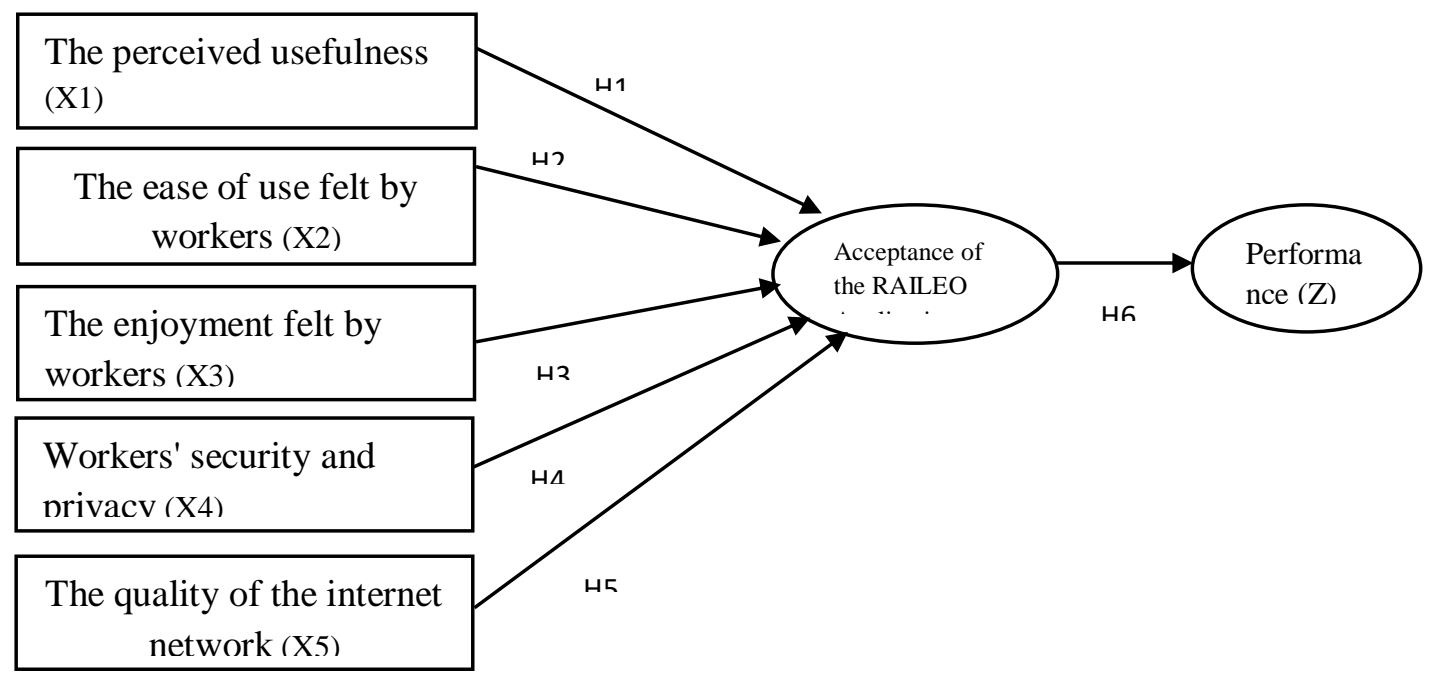




\section{International Journal of Economics, Business and Management Research}

Vol. 6, No.02; 2022

ISSN: $2456-7760$

Source: Tero Pikarainen et al., (2004), Muhammad Hilmi Muzakkki et al., (2016)

Figure 1. Framework

\section{Method}

This research is a type of research with a quantitative approach. Because this study will examine the effect of online presence and its impact on employee performance based on numerical calculations, the data of which is in the form of numbers (scores or scores, ratings, frequencies), which are analyzed using statistics to answer specific research questions or hypotheses. So, this research is a quantitative research.

The population that will be used as research is the employees of PT KAI Daop V Purwokerto with a total population of 498 . From the total population, namely 498, with an inaccuracy leeway of 5\%, using the Slovin formula, the number of samples obtained is 221.82 or 222 respondents.

The data collection method in this study used a questionnaire that was delivered to respondents via a digital link. Questionnaires, namely by compiling a list of questions addressed to respondents regarding the variables studied. To obtain the necessary data, this research used a questionnaire in collecting data, with a list of questions provided to answer questions in writing by the respondents. The questionnaire contains questions, each question is opened up to five possible answers. From the five answers, respondents are expected to choose one answer that is considered the most appropriate for them. Each answer has a score, where 1 strongly agree to 5 strongly disagree. The analysis plan used is descriptive analysis, hypothesis testing, multiple linear regression.

\section{FINDING AND DISCUSSION}

From the results of the study showed that the number of respondents amounted to 257 with a male gender of $55.64 \%$ or 143 respondents and $44.36 \%$ or 114 respondents with a female gender. This is because at PT. KAI Daop V, the average number of employees is male. In addition, respondents are more dominated by respondents aged 26-30 years and 31-35 years, with a percentage of $34.6 \%$ and $28.8 \%$, which means that the average employee at PT. KAI Daop V Purwokerto has a productive working age between 26 to 35 years. Respondents were dominated by respondents whose last education was SMA/equivalent with a percentage of $74.3 \%$, which means that the average employee at PT. KAI Daop V Purwokerto's education level is dominated by high school/equivalent. Respondents are more dominated by respondents who earn 5-10 million per month with a percentage of $47.9 \%$ and 10.1-15 million with a percentage of $34.6 \%$, which means that the average employee of PT. KAI Daop V Purwokerto has a better income when compared to the UMK Banyumas Regency in 2021 of Rp. 1,970,000, - (Central Java Governor's Decree, 2020).

\section{Validity test}

Validity test is used to measure the validity or validity of a questionnaire. The research results are considered valid if there are similarities between the data collected and the data that actually occurs in the object under study. In this case, question items are used which are expected to accurately reveal the measured variables (Widiyanto, 2005). 
International Journal of Economics, Business and Management Research

Vol. 6, No.02; 2022

ISSN: $2456-7760$

Convergent validity is a measurement that measures the extent to which an instrument is highly correlated with other instruments designed to assess the same construct (Cooper \& Schindler, 2014: 259). Convergent Validity testing is done by loading factor and Average Variance Extracted (AVE) with the recommended minimum loading factor value of 0.70 and Average Variance Extracted (AVE) of 0.50 so that it can show adequate convergent validity. The value of Convergent Validity in this study can be seen in table 1

Tabel 1. Loading Factor

\begin{tabular}{|c|c|c|c|c|c|c|c|}
\hline & $\mathrm{X} 1$ & $\mathrm{X} 2$ & $\mathrm{X} 3$ & $\mathrm{X} 4$ & $\mathrm{X} 5$ & Y1 & $\mathrm{Z} 1$ \\
\hline $\mathrm{X} 1.1$ & 0,788 & & & & & & \\
\hline $\mathrm{X} 1.2$ & 0,884 & & & & & & \\
\hline X1.3 & 0,838 & & & & & & \\
\hline $\mathrm{X} 1.4$ & 0,777 & & & & & & \\
\hline X1.5 & 0,817 & & & & & & \\
\hline X1.6 & 0,726 & & & & & & \\
\hline $\mathrm{X} 2.1$ & & 0,659 & & & & & \\
\hline $\mathrm{X} 2.2$ & & 0,671 & & & & & \\
\hline $\mathrm{X} 2.3$ & & 0,626 & & & & & \\
\hline $\mathrm{X} 2.4$ & & 0,617 & & & & & \\
\hline $\mathrm{X} 2.5$ & & 0,585 & & & & & \\
\hline $\mathrm{X} 3.1$ & & & 0,548 & & & & \\
\hline X3.2 & & & 0,584 & & & & \\
\hline X3.3 & & & 0,579 & & & & \\
\hline X3.4 & & & 0,472 & & & & \\
\hline $\mathrm{X} 4.1$ & & & & 0,872 & & & \\
\hline $\mathrm{X} 4.2$ & & & & 0,814 & & & \\
\hline $\mathrm{X} 4.3$ & & & & 0,858 & & & \\
\hline $\mathrm{X} 4.4$ & & & & 0,834 & & & \\
\hline $\mathrm{X} 4.5$ & & & & 0,865 & & & \\
\hline $\mathrm{X} 4.6$ & & & & 0,749 & & & \\
\hline $\mathrm{X} 5.1$ & & & & & 0,888 & & \\
\hline $\mathrm{X} 5.2$ & & & & & 0,902 & & \\
\hline Y1.1 & & & & & & 0,843 & \\
\hline Y1.2 & & & & & & 0,836 & \\
\hline Y1.3 & & & & & & 0,887 & \\
\hline Y1.4 & & & & & & 0,827 & \\
\hline $\mathrm{Z} 1.1$ & & & & & & & 0,852 \\
\hline $\mathrm{Z} 1.2$ & & & & & & & 0,934 \\
\hline Z1.3 & & & & & & & 0,860 \\
\hline$\overline{\mathrm{Z} 1.4}$ & & & & & & & 0,849 \\
\hline $\bar{Z} 1.5$ & & & & & & & 0,833 \\
\hline
\end{tabular}




\section{International Journal of Economics, Business and Management Research}

Vol. 6, No.02; 2022

ISSN: $2456-7760$

\section{Reliability test}

Reliability test was used to measure the consistency of the research construct/variable. A variable is said to be reliable if the respondent's answers to questions are consistent or stable from time to time. The level of reliability of a construct/research variable can be seen from the statistical results of Cronbach Alpha $(\alpha)$. A variable is said to be reliable if it gives a Cronbach alpha value $>0.60$ (Ghozali, 2005). The results of the reliability calculation by SPSS can be seen in table 2 below:

Tabel 2, Reliability Testing Questionnaire

\begin{tabular}{ccc}
\hline Variable & $\begin{array}{c}\text { Nilai Cronbach's Alpha } \\
\text { Based on Standardized }\end{array}$ & Keterangan \\
The perceived usefulness of workers & 0,915 & \\
The ease of use felt by workers & 0,925 & Reliable \\
The enjoyment felt by workers & 0,938 & Reliable \\
Workers' security and privacy & 0,910 & Reliable \\
The quality of the internet network & 0,933 & Reliable \\
Acceptance of the RAILEO Application & 0,914 & Reliable \\
Performance & 0,910 & Reliable \\
\hline
\end{tabular}

From this analysis, Cronbach's alpha value is above 0.600 , meaning that the questionnaire is reliable because it is greater than 0.600 .

\section{Hypothesis testing}

Test the relationship between variables perceived usefulness, ease of use, perceived enjoyment, security and privacy as well as the quality of the internet network on RAILEO Application Recipients

From the results of the $\mathrm{F}$ test in this study, the calculated $\mathrm{F}$ value was 66,124 with a significance number (P value) of 0.000 . With a significance level of $95 \%(\alpha=0.05)$. The significance value ( $\mathrm{P}$ value) is $0.000<0.05$. Or by looking at the value of $\mathrm{F}$, the condition is accepted if F Count $>$ from F Table. It can be seen that in calculating the F Count value is 66,124 and the F Table value is 2.3112 , which means F Count > from F Table or 66,124 > 2.3112. On the basis of this comparison, $\mathrm{H} 0$ is rejected or means that the variables of perceived usefulness, ease of use, perceived enjoyment, security and privacy as well as the quality of the internet network have a significant influence on the variable recipients of the RAILEO Application.

\section{Test the relationship between the receiver variable RAILEO Application on performance}

From the results of the $\mathrm{F}$ test in this study, the calculated $\mathrm{F}$ value was 241,826 with a significance number (P value) of 0.000 . With a significance level of $95 \%(\alpha=0.05)$. The significance value ( $\mathrm{P}$ value) is $0.000<0.05$. Or by looking at the value of F, the condition is accepted if F Count $>$ from F Table. It can be seen that in the calculation the F Count value is 241.826 and the F Table value is 3.9381, which means F Count > from F Table or 241.826 > 3.9381. On the basis of this comparison, $\mathrm{H} 0$ is rejected or it means that the recipient variable of the RAILEO application has a significant influence on the performance variable. 


\section{International Journal of Economics, Business and Management Research}

Vol. 6, No.02; 2022

ISSN: $2456-7760$

\section{Discussion of Research Results}

\section{Perceived usefulness towards acceptance of the RAILEO Application}

In this study, the significance value ( $\mathrm{P}$ Value) is 0.006 which is smaller than the alpha value, which is 0.05 and the regression coefficient value is 0.198 . It can be concluded that the higher the perceived usefulness, the higher the acceptance of the RAILEO Application. From the results of the research conducted, it can be concluded that this study supports the two previous researchers, apart from being based on theory, the reason for the perceived usefulness that affects the acceptance of the RAILEO application is the ease of the system that is felt by employees, this is because employees do not have to be absent in attendance. especially during a pandemic that requires work from home (WFH), this system makes it easier for employees to prove attendance.

\section{User ease of acceptance of the RAILEO Application}

In this study, the significance value (P Value) is 0.043 , which is smaller than the alpha value, which is 0.05 and the regression coefficient value is 0.146 . It can be concluded that the higher the user convenience, the higher the acceptance of the RAILEO Application. The results of the research carried out support the two studies which state that user convenience affects the system, but in this study the system is the RAILEO application. In addition to the theory above, this research can be explained by phenomena. The phenomenon that occurs is that it is relatively easy for employees to be absent at work, this is because during the pandemic that occurred they required them to continue to work even at home. Therefore, employees feel the ease of setting work attendance in this system.

\section{The pleasure felt towards receiving the RAILEO Application}

In this study, the significance value (P Value) is 0.480 , which is greater than the alpha value, which is 0.05 and the regression coefficient value is 0.051 . It can be concluded that the more enjoyment you feel, the higher the acceptance of the RAILEO Application. This study does not support the research conducted by Terro Pikkarainen, et al., (2004) who stated that they found that perceived pleasure had a significant impact on intention to use the Internet. In addition, this study also does not support research conducted by Davis et al., (1992) which states that enjoyment refers to the extent to which activities using computers are considered enjoyable by themselves. Perceived enjoyment is positively correlated with time of use but not with frequency of use or number of tasks (Igbaria et al., 1995). In contrast, Teo et al., (1999) noted that perceived enjoyment was positively correlated with the frequency of daily internet use. From some of the studies above which reveal that the perceived enjoyment affects the system, but in this study it does not support this research, this is due to the phenomena that occur in the field, the system records the time workers perform attendance attendance, the punish of delays in attendance will affect in terms of the benefits to be given.

\section{Security and privacy of receiving the RAILEO Application}

In this study, the significance value (P Value) is 0.005 , which is smaller than the alpha value, which is 0.05 and the regression coefficient value is 0.259 . It can be concluded that the higher the security and privacy, the higher the acceptance of the RAILEO Application. This study supports the research conducted by Terro Pikkarainen, et al., (2004) which states that security and privacy do not have a significant effect on online banking acceptance. This is related to 


\section{International Journal of Economics, Business and Management Research}

Vol. 6, No.02; 2022

ISSN: $2456-7760$

previous research which explained in the application of online systems that privacy and security were found to be significant barriers to online banking adoption in Australia (Sathye, 1999). In this study, it supports the research conducted by previous researchers who stated that security and privacy affect the system, the system in this study is the RAILEO application. This is because workers who are at PT. Kereta Api Indonesia (Persero) DAOP V Purwokerto, has used the system and the system is an internal company that serves to facilitate work, especially digital attendance and personal data of workers is safe in the system.

\section{The quality of the internet network on the acceptance of the RAILEO Application}

In this study, the significance value ( $\mathrm{P}$ Value) is 0.001 which is greater than the alpha value, which is 0.05 and the regression coefficient value is 0.664 . It can be concluded that the higher the quality of the internet network, the higher the acceptance of the RAILEO Application. This study supports the results of research conducted by Tero Pikkarainen, et al., (2004) stating the internet quality factor implies that the speed and reliability of the internet connection is not considered important due to the fact that a reliable internet connection has become common among the respondents. In addition, the research conducted by Windi et al., (2020) stated that the factor that hinders the effectiveness of the application of fingerprint attendance at BPPKAD Brebes Regency is that the attendance facility or machine often experiences errors, thus hampering the process of recording employee attendance because the system is based online when the network is on. is experiencing a disturbance, then the activities in BPPKAD will be disrupted. This study supports the theory of previous research results, phenomena that occur in the field, the system will be able to run if it is accessed by the internet, if there is no internet, then the system cannot be used, because this system requires access to the location of the workers located and the IP address used.

\section{RAILEO App acceptance on performance}

In this study, the significance value (P Value) is 0.000 , which is smaller than the alpha value, which is 0.05 and the regression coefficient value is 1.051 . It can be concluded that the higher the acceptance of the RAILEO Application, the higher the performance. This study supports research conducted by Muhammad Hilmi Muzakkki, et al., (2016) which states that Information Technology has a significant influence on employee performance simultaneously and partially. In addition, another study conducted by Astuti Handaiyani Siregar, et al., (2009) that the use of technology has a positive and significant effect on individual performance at the West Denpasar Pratama Tax Service Office. Based on the results of this study, online presence which is the result of technological developments is expected to improve employee performance. This study supports the previous research based on the theory of the results obtained. In addition to theory, the results of this study can be explained phenomenally. The phenomenon that occurred at the time of the research, the system used by workers greatly facilitated them in working, especially when the Covid-19 outbreak appeared in early 2020 which required all workers to work at home. This system is very helpful for workers in doing work such as attendance attendance, making SPPD and assignment letters without having to go to the office. This makes employee performance increase. 


\section{International Journal of Economics, Business and Management Research}

Vol. 6, No.02; 2022

ISSN: $2456-7760$

\section{Conclusion and Recommendation}

Specifically, this research can be concluded that the perceived usefulness affects the acceptance of the RAILEO application, the ease of use affects the acceptance of the RAILEO application, the perceived enjoyment does not affect the acceptance of the RAILEO application, security and privacy affect the acceptance of the RAILEO application, the quality of the internet network affects the acceptance of the application. RAILEO and RAILEO Application affect performance.

Each study has its shortcomings and limitations, including in this study. Among them: First, this research was conducted at PT. Kereta Api Indonesia (Persero) DAOP V Purwokerto by using online questionnaires does not directly distribute questionnaires or meet in person and wait for respondents to fill out, so the target in returns that should be $100 \%$, is not optimal because questionnaires are distributed and researchers are waiting for responses from respondents to fill out the questionnaire. Second, apart from the online questionnaires, the limitation of this research is the application for RAILEO admissions, which are mostly employees of PT. The Daop V Purwokerto Railway, has not been optimal in using the application, what employees only know is that the application is only for online attendance.

From the above limitations, the recommendation for further research is to first provide training to employees regarding the RAILEO acceptance application, this is important so that employees understand the maximum content of the application; the second is in collecting online questionnaires so that they are maximized, it can be done by conducting online meetings so that the intent and purpose of this research can be known and can provide direct questionnaires and can be filled in directly with the questionnaire.

\section{References}

Agil Rakhmansyah, M. Al Musadieq, Heru Susilo. 2014. Pengaruh Penggunaan Teknologi Informasi Terhadap Kinerja (Studi pada karyawan PT. PLN Area Madiun). Jurnal Administrasi Bisnis., Vol.14 No.1 September 2014.

Arifin, Jabal Firdaus dan Suryo Pratolo. 2012. "Pengaruh Kualitas Sistem Informasi Keuangan Daerah terhadap Kepuasan Aparatur Pemerintah Daerah Menggunakan Model Delone Dan Mclean". Jurnal Akuntansi \& Investasi. Vol. 13 No. 1, hal: 28-34.

Astuti Handayani Siregar, I Ketut Suryanawa. 2009. Pemanfaatan Teknologi Informasi dan Pengaruhnya Terhadap Kinerja Individual Pada Kantor Pelayanan Pajak Pratama Denpasar Barat. Jurnal Ilmiah Akuntansi dan Bisnis. Vol.4 No.2. 2009.

Boyle Ian O, 2013. Individual Performance Management: A Review of Current Practices. AsiaPacific Management and Business Application, 1, 3 (2013): 157-170. ISSN: 2252-8997.

Cranor, L.F., Reagle, J. and Ackerman, M.S. (1999), 'Beyond concern: understanding net users' attitudes about online privacy", technical report, TR 99.4.3, AT\&T Labs - Research, available at: www.research.att.com/resources/trs/TRs/99/99.4/99.4.3/report.htm.

Creswell, J. W. (2014). Research design: Qualitative, quantitative, and mixedmethods approaches (4th edition). California: SAGE Publications, Inc. 


\section{International Journal of Economics, Business and Management Research}

Vol. 6, No.02; 2022

ISSN: $2456-7760$

Danish, R. Q., Ramzan, S. R., \& Ahmad, F. (2013). Effect of Perceived Organizational Support and Work Environment on Organizational Commitment; Mediating Role of SelfMonitoring. Advances in Economics and Business, 1(4): 312-317.

Davis, F.D. (1989), "Perceived usefulness, perceived easy of use, and user acceptance of information technology", MIS Quarterly, September, pp. 319-40. Jalagat.

Davis, F.D., Bagozzi, R.P. and Warshaw, P.R. (1992), "Extrinsic and intrinsic motivation to use computers in the workplace", Journal of Applied Social Psychology, Vol. 22 No. 14, pp. 1111-32.

Eisenberger, R., Fasolo, P. and LaMastro, V.D. 1990, "Perceived organizational support and employee diligence, commitment, and innovation", Journal of Applied Psychology, Vol. 75 No. 1, pp. 51- 59.

Erdogan, B. dan Enders, J. (2007), "Support from the Top: Supervisors' Perceived Organizational Support as a Moderator of Leader-Member Exchange to Satisfaction and Performance Relationships", Journal of Applied Psychology, Vol. 92, No. 2, pp. 321-330.

Heriyati, Prasetyo Arfan.2018. Analisis Pengaruh Kemanfaatan Sistem Presensi Berbasis Finger Print Terhadap Kemudahan Bagi Karyawan Pada PT. Lucky Samudra Pratama. Jurnal Teknologi Informatika \& Komputer. Vol. 4, No. 2, September 2018.

Hertayana, Hylenarti, 2016, Pengaruh Sistem Absensi Fingerprint Terhadap Kinerja Karyawan Pada PT. Deltacomsel Indonesia. Jurnal Teknik Komputer AMIK BSI, Vol II, No. 2, Agustus 2016.

Howcroft, B., Hamilton, R. and Hewer, P. 2002, "Consumer attitude and the usage and adoption of home-based banking in the United Kingdom", The International Journal of Bank Marketing, Vol. 20 No. 3, pp. 111-21.

Hon, Alice H. Y. (2013). "The Effects of Group Conflict and Work Stres on Employee Peformances". Journal Tourism Management.

https://ppid.kai.id

https://eoffice.kai.id

Igbaria, M., Iivari, J. and Maragahh, H. 1995, "Why do individuals use computer technology? A Finnish case study", Journal Information \& Management, Vol. 29, pp. 227-38.

Jurica Lucyanda, 2010, Pengujian Technology Acceptance Model (TAM) dan Theory Planned Behavior (TPB). JRAK, Vol.2 Agustus. 2010.

Khoirul Muhtajib - Mochamad Sidqon, S.Si., M.Si., 2020. Aplikasi Presensi Online Menggunakan IMEI Dan GPS Pada Smartphone Android.

Keputusan Gubernur Jawa Tengah, 2020, Upah Minimum Pada 35 (Tiga Puluh Lima) Kabupaten/Kota di Provinsi Jawa Tengah Tahun 2021, Nov 2020, Semarang.

Mahfud Safudin. 2017. Pengaruh Penerapan Absensi Online Terhadap Disiplin Pada Karyawan Purple Express Laundry Jakarta. Indonesian Journal on Software Engineering. Vol 3 No $2-2017$. 


\section{International Journal of Economics, Business and Management Research}

Vol. 6, No.02; 2022

ISSN: $2456-7760$

Mangkunegara, A. P. 2007. Manajemen Sumber DayaManusia Perusahaan. Bandung: PT. Remaja Rosdakarya.

Muhamad Sham Shahkat Ali \& Menatullah Nasr. 2016.The Effects of a Brand's Online Presence on Brand Awareness and Brand Loyalty: A Study of UAE Millennials. International Journal of Media, Journalism and Mass Communications (IJMJMC). Volume 2, Issue 1, 2016, PP 39-50. ISSN 2454-9479. http://dx.doi.org/10.20431/2454-9479.0202004.

Nasrizal Akbar, Vince Ratnawati, Vina Novita. 2010. Pengaruh Pengetahuan Teknologi Informasi, Pemanfaatan Teknologi Informasi dan Faktor Kesesuaian Tugas-Teknologi Terhadap Kinerja Akuntan Internal. Jurnal Ekonomi.Volume 18, No.2, Juni 2010.

Nizar Zakaria. 2016. Pengaruh Efektivitas Penerapan Sistem Presensi Electronic Data Capture (edc) dan Budaya Organisasi Terhadap Disiplin Kerja Karyawan PT. Bank Rakyat Indonesia (Persero) TBK Kantor Cabang Pare. Jurnal Revitalisasi Jurnal Ilmu Manajemen. Vol.5 Nomor 3, September 2016.

Prayogi Abd. Jalil. 2018. Pengaruh Kompensasi dan Disiplin Kerja Terhadap Kinerja Karyawan Pada PT. Candana Putra Nusantara. Jurnal Manajemen Bisnis. Volume 8 No.1. Edisi April 2018.

Roboff, G. and Charles, C. (1998), "Privacy of financial information in cyberspace: banks addressing what consumers want", Journal of Retail Banking Services, Vol. XX No. 3, pp. 51-6.

Saiful Rahman Yuniarto. (2016), "Pengaruh Penggunaan Teknologi Informasi Terhadap Kinerja Karyawan (Studi Pada Karyawan PT. Telkom Pusat Divisi Regional V Surabaya)", Jurnal Administrasi Bisnis (JAB). Vol. 39 No.2 Oktober 2016.

Sathye, M. (1999), "Adoption of Internet banking by Australian consumers: an empirical investigation", International Journal of Bank Marketing, Vol. 17 No. 7, pp. 324-34.

Sedarmayanti, 2007, Sumber Daya Manusia dan Produktivitas Kerja. Bandung, Penerbit Mandar Maju.

Siti Nur Aini Hidayati, Kintan Cahya Oktaviani. 2020. Faktor-Faktor Internal dan Eksternal yang dapat Mempengaruhi Disiplin Kerja Karyawan Perusahaan. Prosiding Seminar Nasional 2020. "Penguatan Pendidikan Karakter Pada Era Merdeka Belajar". Surabaya, 19 September 2020.

Tero Pikkarainen, Kari Pikkarainen, Heikki Karjaluoto and, Seppo Pahnila. 2004. Consumer acceptance of online banking: an extension of the technology acceptance model. JournalInternet Research. Volume 14 -Number $3 \cdot 2004 \cdot 224-235$.

Teo, T.S.H., Lim, V.K.G. and Lai, R.Y.C. (1999), "Intrinsic and extrinsic motivation in Internet usage", Omega, International Journal of Management Science, Vol. 27, pp. 25-37.

Venkatesh, Viswanath Fred D. Davis. 2000. A The oritical Extension of the Technology Acceptance Model: Four Longitudinal Field Studies. Journal Management Science. Vol. 46, No. 2, pp. 186-204. 
International Journal of Economics, Business and Management Research

Vol. 6, No.02; 2022

ISSN: $2456-7760$

Westin, A.F. and Maurici, D. (1998), "E-commerce \& privacy: what the net users want", Privacy \& American Business, and PricewaterhouseCoopers LLP, New York, NY, available at: www.pwcglobal.com/gx/eng/svcs/privacy/images/E-Commerce.pdf.

Windy Oktafiana., Slamet Bambang Riono, Muhammad Syaifulloh, 2020. Pengaruh Efektivitas Penerapan Absensi Finger Print Di Badan Pengelolaan Pendapatan Keuangan Dan Aset Daerah (Bppkad) Kabupaten Brebes. Journal Economics and Management (JECMA), Volume 1, No.01, Agustus 2020. 